\title{
Immunohistochemical Expressions of the Antimicrobial Peptides (hBD-3 and hCAP-18/LL-37) in Colon, Stomach and Lung Adenocarcinomas
}

\author{
Murat KILIC $^{1}$, Serpil OGUZTUZUN² ${ }^{2}$ Gulcin SIMSEK ${ }^{3}$, Ebru CAKIR ${ }^{4}$ \\ ${ }^{1}$ Ankara University, Vocational School of Health Services, Department of Pharmacy Services, Ankara \\ ${ }^{2}$ Kirikkale University, Faculty of Arts and Sciences, Department of Biology, Kirikkale \\ ${ }^{3}$ Kecioren Training and Research Hospital, Department of Pathology, Ankara \\ ${ }^{4}$ Inonu University, Faculty of Medicine, Department of Pathology, Malatya. TURKEY
}

\begin{abstract}
This study investigated the immunohistochemical staining characteristics of human beta defensin-3 (hBD-3) and human cationic antimicrobial peptide-18/cathelicidin (hCAP-18/LL-37) in colon, stomach and lung adenocarcinomas and normal tissues (periphery to tumor tissues) from 22, 24 and 24 patients, respectively. Expressions of hBD-3 and hCAP-18/LL-37 were assessed by immunohistochemistry for colon, stomach and lung adenocarcinomas of 70 patients from Atatürk Chest Diseases and Thoracic Surgery Training and Research Hospital and Keçiören Training and Research Hospital. both located in Ankara, Turkey. The differences between the expressions of hBD-3 and hCAP-18/LL-37 in normal and carcinoma tissues were analyzed by Mann-Whitney U Test. When the normal and tumor tissues of these cases were compared according to their staining intensity of positive staining. the hBD-3 and hCAP-18/ LL-37 expressions in colon, stomach and lung adenocarcinomas cells were significantly higher than those in normal cells $(p<0.05)$. Immunostaining of HBD-3 and hCAP-18/LL-37 was found to be a marker of malignancy in colon. stomach and lung adenocarcinomas. The expressions of hBD-3 and hCAP-18/LL-37 were, for the first time, shown to be significantly altered in colon, stomach and lung adenocarcinomas as compared to controls. In conclusion, the present findings suggest that beside the antimicrobial activity of Antimicrobial Peptides (AMPs), hBD-3 and hCAP-18/LL-37 can also play a role in the pathogenesis of colon. stomach and lung adenocarcinomas.
\end{abstract}

Keywords: Adenocarcinoma, hBD-3, hCAP-18/LL-37, Immunohistochemistry

ÖZET

Kolon, Mide ve Akciğer Adenokarsinomlarında hBD-3 ve hCAP-18/LL-37 Antimikrobiyal Peptidlerin İmmunohistokimyasal Ekspresyonu

Bu çalışma, sırasıyla 22, 24 ve 24 kolon, mide ve akciğer adenokanserli hastaların tümörlü ve tumor periferinde bulunan normal dokularında human Beta Defensin-3 (hBD-3) ve insan katyonik antimikrobiyal peptid-18/cathelicidin (hCAP-18/LL-37)'nin immunohistokimyasal boyanma özelliklerini araştırmıştır. Atatürk Göğüs Hastalıkları ve Göğüs Cerrahisi Eğitim ve Araştırma Hastanesi ve Keçiören Eğitim ve Araştırma Hastanelerinden alınan toplam 70 kolon, mide ve akciğer adenokanserli hastalarda, hBD-3 ve hCAP-18/LL-37 ekspresyonları immunohistokimya ile değerlendirildi. Normal ve karsinomalı dokularda hBD-3 ve hCAP-18/LL-37 ekspresyon farkllıklar istatistiksel olarak Mann-Whitney $U$ Test ile analiz edildi. Bu hastalıklarda normal ve tümörlü dokularda, pozitif boyanma şiddetleri karşılaştırılığında, kolon, mide ve akciğer adenokanserli dokularda hBD-3 ve hCAP-18/LL-37 ekspresyonlarının normal dokulara oranla daha fazla olduğu istatistiksel olarak anlamlı bulundu ( $p<0.05)$. hBD-3 ve hCAP-18/LL-37 immunoboyamasının kolon, mide ve akciğer adenokanserinde malignitenin bir belirteci olabileceği bulunmuştur. Normal dokularla karşılaştııldığında, tümörlü dokularda, hBD-3 ve hCAP-18/LL-37 ekspresyonlarının önemli ölçüde değişmiş olduğu ilk kez gösterilmiştir. Sonuç olarak, mevcut bulgular, hBD-3 ve hCAP-18/LL-37 antimikrobiyal peptidlerinin kolon, mide ve akciğer adenokanserlerinin patogenezinde rol oynayabileceğini desteklemektedir.

Anahtar Kelimeler: Adenokarsinoma, hBD-3, hCAP-18/LL-37, İmmünohistokimya 


\section{INTRODUCTION}

Antimicrobial peptides (AMPs) are molecules of the innate immune system with antimicrobial activity. ${ }^{1}$ The defensins and the cathelicidins are the two families of AMPs expressed in mammals. AMPs are expressed in epithelial cells and host defense cells such as macrophages and neutrophils. In addition. AMPs have diverse activities on various cell types. Some of these activities are related to the biology of cancer. ${ }^{2}$

Studies on another group of defensins reported that hBD (human beta defensin)-1 is down-regulated in prostate and renal carcinomas. ${ }^{3-5}$ While an increased expression of hBD-1 and hBD-2 was observed in the tumor compared to normal in basal cell carcinoma, hBD-3 in normal tissue is not different from that in tumor tissue. ${ }^{6}$ Considering the role of hBDs in lung cancer, $\mathrm{hBD}-2$ expression is lower in low-differentiated lung adenocarcinoma than that in moderately differentiated lung adenocarcinoma. ${ }^{7}$ A number of studies demonstrated the possible involvement of hBDs in tumorigenesis of human squamous cell carcinomas, and cervix carcinomas. ${ }^{8-10}$ Defensins may play a role in the progression of human gastric tumors. In vitro studies proved the induction of hBD-2 expression in response to infection with $H$. pylori and are supported in clinical setting indicating that hBD-2 is differentially expressed with respect to $\mathrm{H}$. pylori status. ${ }^{11-13}$ However. in another study. hBD-1 and hBD-2 overexpression was revealed both in $\mathrm{H}$. pylori-positive and $H$. pylori-negative gastric biopsy samples from patients with gastritis. ${ }^{14.15}$

Human cationic antimicrobial peptide-18 (hCAP18/LL-37) is the only cathelicidin present in humans and it has several properties that might be relevant for the progression of tumors. ${ }^{16}$ Expression of hCAP-18/LL-37 is up-regulated in various ovarian tumor subtypes, including serous adenocarcinomas. mucinous adenocarcinomas and granulosa cell tumors, compared with normal ovarian tissues ${ }^{17}$; it is highly up-regulated in human breast cancer tissues. compared with normal breast tissues. ${ }^{18}$ It has been shown that hCAP-18/ LL-37 stimulates proliferation of cultured lung cancer cells and promotes tumorigenicity in a lung cancer xenograft model. ${ }^{19}$ It has been observed that
hCAP-18/LL-37 is expressed at very low levels in gastric hyperplastic polyps, tubular adenomas and adenocarcinomas. ${ }^{20}$

In this study, we assessed the cellular prevalence and distribution of human beta defensin-3 (hBD3) and LL37/ hCAP-18 in human tissue samples of stomach. colon and lung adenocarcinomas and normal tissues (periphery to tumor tissues from same patients).

\section{PATIENTS AND METHODS}

\section{Patients}

The study included 24 patients with stomach (18 male, 6 female, mean age $68.38 \pm 3.12$ years). 22 patients with colon (20 male, 2 female, mean age $69.72 \pm 3.61$ years) and 24 patients with lung (21 male, 3 female, mean age $65.49 \pm 2.98$ years) adenocarcinomas, who were diagnosed and treated at Atatürk Chest Diseases and Thoracic Surgery Training and Research Hospital and Kecioren Training and Research Hospital, both in Ankara, Turkey. Archive materials were taken so that one from the tumor tissue and one from the macroscopically normal tissue peripheral to the tumor tissue were selected. Detection of $H$. pylori status in patients with stomach cancer was performed by GIEMSA staining.

\section{Immunohistochemical Staining}

Sections that were $4 \mu \mathrm{m}$ thick were cut. and one section was stained with haemotoxylin-eosin to observe the tissue morphology. For immunohistochemistry, endogenous peroxidase activity was blocked by incubating the sections in $1 \%$ hydrogen peroxide $(\mathrm{v} / \mathrm{v})$ in methanol for 10 minutes at room temperature (RT). The sections were subsequently washed in distilled water for 5 minutes, and then antigen retrieval was performed for 3 minutes using $0.01 \mathrm{M}$ citrate buffer $(\mathrm{pH} 6.0)$ in a domestic pressure cooker. The sections were transferred in $0.05 \mathrm{M}$ Tris $-\mathrm{HCl}(\mathrm{pH}$ 7.6) containing $0.15 \mathrm{M}$ sodium chloride (TBS). After washing in water, the sections were incubated at RT for 30 minutes with either normal swine serum (Dakopatts. Denmark) (1:20) diluted in TBS to block nonspecific 
binding. The sections were then covered with the primary antibodies diluted 1:500 for anti-hBD-3 and hCAP-18/LL-37 in TBS at $4^{\circ} \mathrm{C}$ overnight. Anti-hBD-3 (cat. no: H-072-42) was from Phoenix Pharmaceuticals. Inc. USA. and anti- hCAP-18/ LL-37 (cat. no: sc-166770) was from Santa Cruz Biotechnology. Inc. USA. After washing in TBS (15 minutes) the sections were incubated at RT for one hour with the secondary antibody (swine-antirabbit Ig-biotinylated (Dakopatts. Denmark)) at a dilution of $1: 100$. Then it was followed by a treatment with avidin-biotin peroxidase complex (Dakopatts. Denmark). Diaminobenzidine was used to visualize the peroxidase activity in the tissues. Nuclei were lightly counterstained with haemotoxyline and then the sections were dehydrated and mounted. Both positive and negative controls were included in each run. Positive controls consisted of sections of tonsillitis tissues for hBD-3 and hCAP18/LL-37. TBS was used in place of the primary antibody for negative controls.

Light microscopy of immunohistochemically stained sections was performed by a pathologist and a biologist who were blinded to the clinical information of the patients. Distribution, localization and characteristics of immunostaining were recorded. Brown color in cytoplasm and/or nucleus of the epithelial cells was evaluated as positive staining. Scoring was also performed by the same observers. Scoring differences between the observers were resolved by consensus. Staining of epithelial cells was diffuse. For each antibody, immunoreactivity (cytoplasmic staining) was graded on a scale of 0 - 3 (scale 0 , all cells negative; scale 1 , weakly positive cells; scale 2 , moderate staining cells; scale 3 , strong positive staining cells). ${ }^{21}$

\section{Statistical Analysis}

For each peptide. staining scores in normal and cancer epithelium were compared statistically. Statistical analyses were performed with the SPSS software (Statistical Package for the Social Sciences. version 15.0. SSPS Inc. Chicago. IL. USA). The differences between the expressions of the hBD-3 and hCAP-18/LL-37 in normal and carcinoma tissues and the differences between the expressions of the hBD-3 and hCAP-18/LL-37 in normal and stomach adenocarcinoma tissues in the presence of $H$. pylori were analyzed by Mann-Whitney Test. The relationship between the expression of the peptides and the age and sex of the patients were

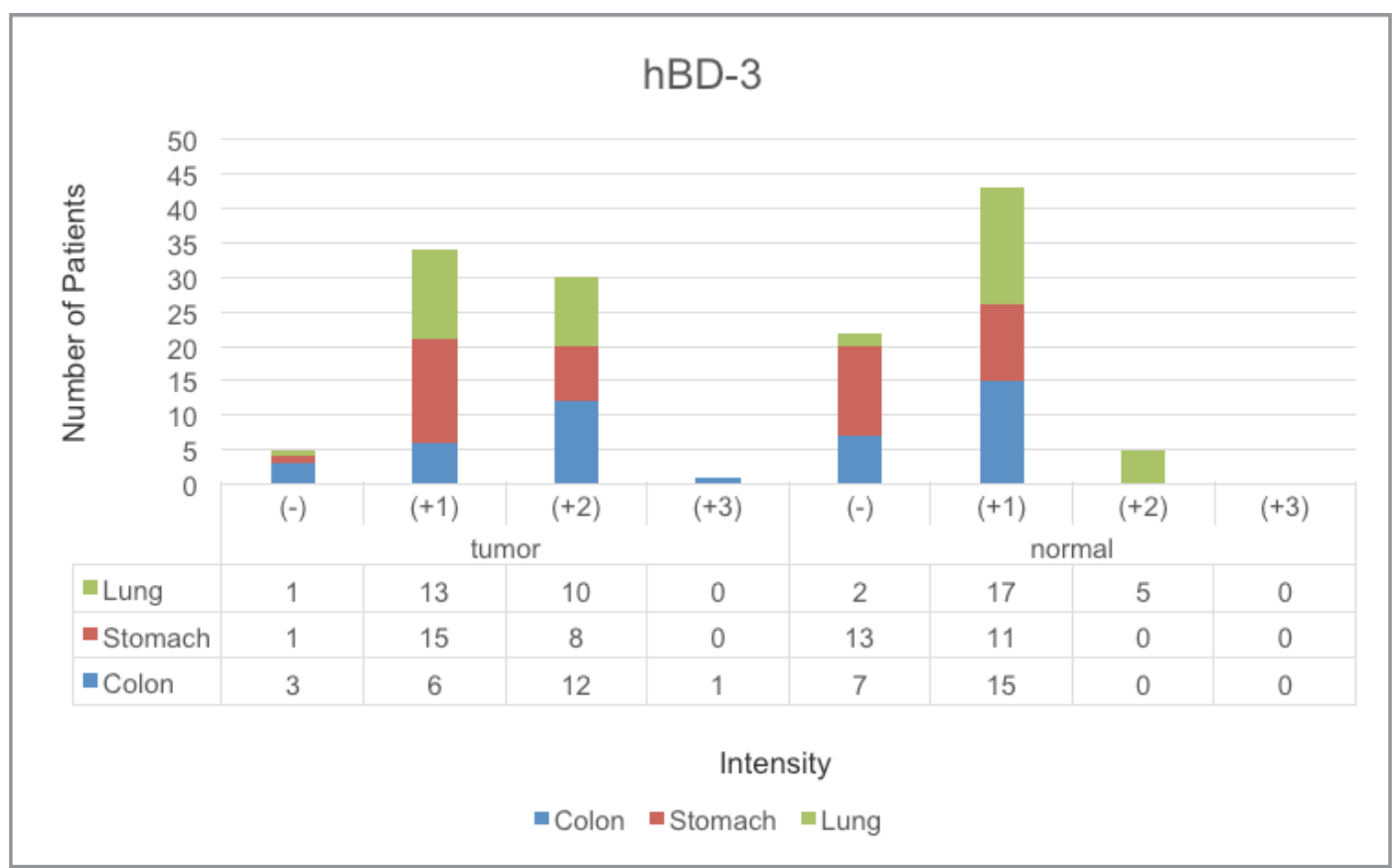

Figure 1. Immunohistochemical staining intensity of hBD-3 expression in tumor and normal tissues of patients with colon, stomach and lung adenocarcinomas 


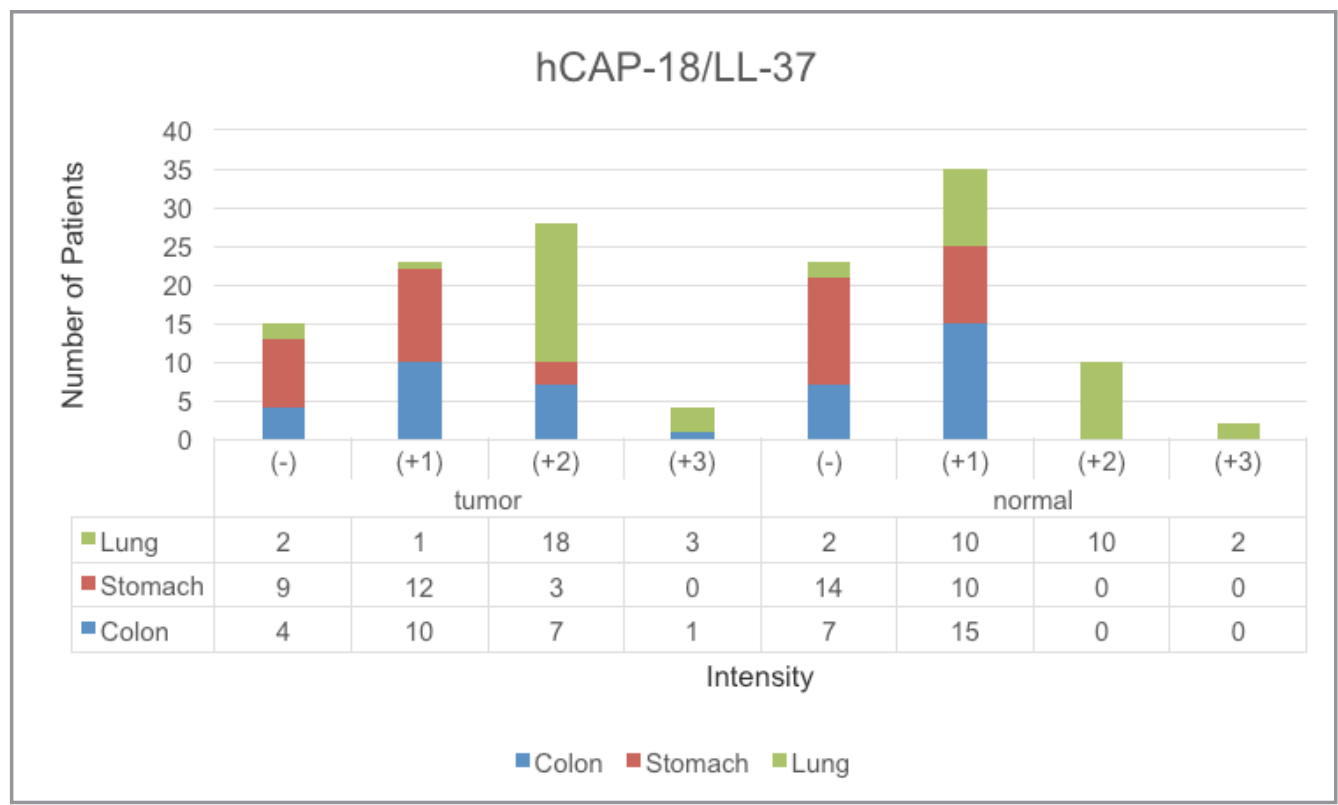

Figure 2. Immunohistochemical staining intensity of hCAP-18/LL-37 expression in tumor and normal tissues of patients with colon, stomach and lung adenocarcinomas

investigated with Spearman's Rank Correlation test. A p value of less than 0.05 was considered as statistically significant.

\section{RESULTS}

Colon, stomach and lung adenocarcinoma and normal samples from the surrounding tissue were examined from 22, 24 and 24 patients, respectively. The hBD-3 expressions in the tumor and normal tissues of patients with colon, stomach and lung adenocarcinomas were compared (Figure 1). Similarly, the HCAP-18/LL-37 expressions were compared between the tumor and normal tissues of patients with colon, stomach and lung adenocarcinomas (Figure 2). HBD-3 expression was showed in tumor tissues of colon, stomach and lung adenocarcinomas (Figure 3a, 3d, 3g). HCAP-18/LL-37 expression was showed in tumor tissues of patients with colon, stomach and lung adenocarcinomas (Figure 3b, 3e, 3h). There was negative control staining in colon, stomach and lung adenocarcinomas (Figure 3c, 3f, 3i).

The expression of antimicrobial peptides in tumor and normal tissues of patients with colon, stomach and lung adenocarcinomas was given in Table 1. Accordingly, hBD-3 was found to be expressed in tumor tissues of 19/22 (86.36\%) and normal tissues of $15 / 22(68.18 \%)$ patients with colon cancer; tumor tissues of 23/24 (95.83\%) and normal tissues of 11/24 (45.08\%) patients with stomach cancer; tumor tissues of 23/24 (95.83\%) and normal tissues of 22/24 (91.66\%) patients with lung adenocancer. The hCAP-18/LL-37 was expressed in tumor tissues of 18/22 (81.81\%) and normal tissues of $15 / 22(68.18 \%)$ patients with colon adenocancer; tumor tissues of 15/24 (62.5\%) and normal tissues of 10/24 (41.66\%) patients with stomach adenocancer; and tumor tissues of 22/24 (91.66\%) and normal tissues of 22/24 (91.66\%) patients with lung adenocancer (Table 1).

HBD-3 and hCAP-18/LL37 expressions between tumor and normal tissues in patients with colon, stomach and lung adenocancer were given in Table 2. The results showed that hBD-3 and hCAP-18/ LL37 expressions in tumor tissues of patients with colon adenocancer were significantly higher than those in normal tissues (phBD-3 $=0.000<0.05$ and phCAP-18/LL-37=0.0299<0.05). The hBD-3 expression in tumor tissues of patients with stomach adenocancer was significantly higher than that in normal tisseus (phBD-3 $=0.0001<0.05$ ). The hCAP18/LL-37 expression in tumor tissues of patients with stomach adenocancer was higher than that 

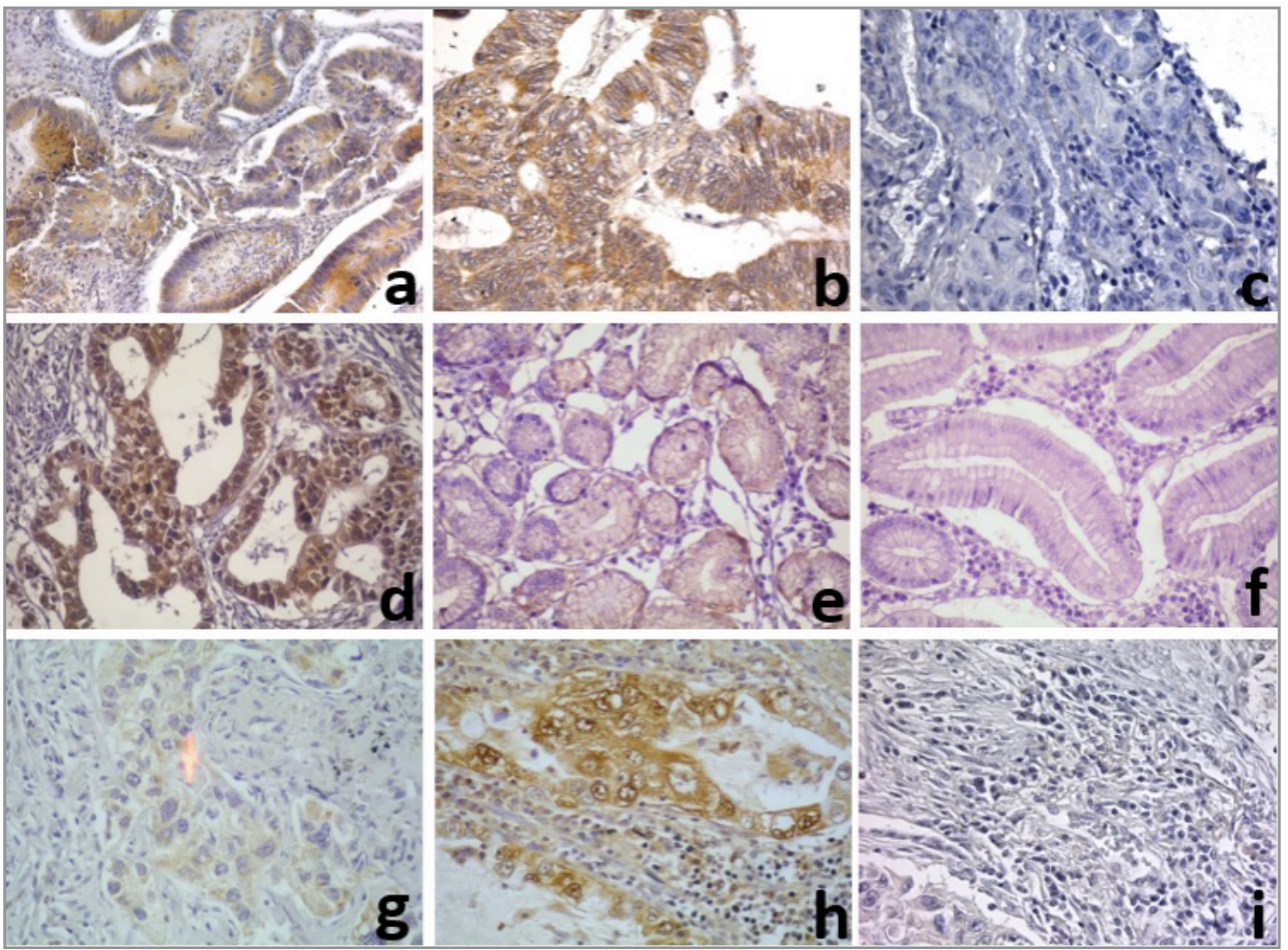

Figure 3. Immunohistochemical Expression of hBD-3 and hCAP-18/LL-37 Antimicrobial Peptides in Colon. Stomach and Lung Adenocarcinomas Tissues. (a) moderate (+2) hBD-3 expression in colon adenocarcinoma (200X). (b) strong (+3) hCAP-18/LL-37 expression in colon adenocarcinoma (200X). (c) negative control staining without antibody in colon adenocarcinoma (200X). (d) moderate (+2) hBD-3 expression in stomach adenocarcinoma (200X). (e) weak (+1) hCAP-18/LL-37 expression in stomach adenocarcinoma (200X). (f) negative control staining without antibody in stomach adenocarcinoma (200X). (g) weak (+1) hBD-3 expression (arrow) in lung adenocarcinoma (200X). (h) strong (+3) hCAP-18/LL-37 expression in lung adenocarcinoma (200X). (i) negative control staining without antibody in lung adenocarcinoma (200X)

in normal tissues, but this result was not statistically significant (phCAP-18/LL-37=0.1245>0.05). The hBD-3 and hCAP-18/LL37 expressions in tumor tissues of patients with lung adenocancer were higher than normal tissues. The differences of hCAP-18/LL-37 expressions between tumor and normal tissues in patients with lung adenocancer were statistically significant (phCAP-18/

Table 1. Expressions of AMPs in colon, stomach and lung normal and tumor tissues

\begin{tabular}{|c|c|c|c|c|c|}
\hline \multirow[b]{2}{*}{ Tumor type } & \multirow[t]{2}{*}{ nTotal } & \multicolumn{2}{|c|}{ hBD-3 } & \multicolumn{2}{|c|}{ hCAP-18/LL-37 } \\
\hline & & nTumor/n\% & nNormal/n\% & nTumor/n\% & nNormal/n\% \\
\hline Colon & 22 & 19/86.36 & $15 / 68.18$ & $18 / 81.81$ & $15 / 68.18$ \\
\hline Stomach & 24 & 23/95.83 & $11 / 45.083$ & $15 / 62.5$ & $10 / 41.66$ \\
\hline Lung & 24 & 23/95.83 & 22/91.66 & 22/91.66 & 22/91.66 \\
\hline
\end{tabular}

The staining scores were calculated based on the sum of the staining intensity and the percentage of positively stained neoplastic and non-neoplastic epithelial cells. Staining intensity was graded as: 0 for no. 1 for weak. 2 for moderate and 3 for strong stainings.

*: Percentages are given by rows. 


\begin{tabular}{|c|c|c|c|c|c|c|c|}
\hline \multirow[b]{2}{*}{ Tumor Type } & \multirow[b]{2}{*}{$\mathbf{n}$} & \multicolumn{3}{|c|}{ hBD-3 } & \multicolumn{3}{|c|}{ hCAP-18/LL-37 } \\
\hline & & Tumor & Normal & $\begin{array}{l}\mathrm{T} / \mathrm{N}^{\star} \\
\mathrm{p}^{\star \star} \text { Value }\end{array}$ & Tumor & Normal & $\begin{array}{l}\mathrm{T} / \mathrm{N} \\
\mathrm{p} \text { Value }\end{array}$ \\
\hline \multirow[t]{2}{*}{ Colon } & 22 & $1.50 \pm 0.17^{\mathrm{a}}$ & $0.68 \pm 0.1$ & 2.20 & $1.23 \pm 0.17$ & $0.68 \pm 0.1$ & 1.80 \\
\hline & & $(0-3)^{b}$ & $(0-1)$ & 0.0009 & $(0-3)$ & $(0-1)$ & 0.0299 \\
\hline \multirow[t]{2}{*}{ Stomach } & 24 & $1.29 \pm 0.11$ & $0.46 \pm 0.10$ & 2.80 & $0.75 \pm 0.14$ & $0.42 \pm 0.10$ & 1.78 \\
\hline & & $(0-2)$ & $(0-1)$ & 0.0001 & $(0-2)$ & $(0-1)$ & 0.1245 \\
\hline \multirow[t]{2}{*}{ Lung } & 24 & $1.38 \pm 0.12$ & $1.13 \pm 0.11$ & 1.22 & $1.92 \pm 0.15$ & $1.5 \pm 0.16$ & 1.28 \\
\hline & & $(0-2)$ & $(0-2)$ & 0.1869 & $(0-3)$ & $(0-3)$ & 0.0489 \\
\hline \multicolumn{8}{|c|}{$\begin{array}{l}\text { The staining scores were calculated based on the } s \\
\text { epithelial cells. Staining intensity was graded as: } 0 \\
{ }^{\star}: \text { Tumor/Normal Ratio } \\
{ }^{* \star} p<0.05 \text { is accepted as statistically signifcant } \\
\text { a: Mean } \pm \text { SE } \\
\text { b: minimum ve maximum staining intensity score } \\
n: \text { number of patients }\end{array}$} \\
\hline
\end{tabular}

LL-37=0.0489<0.05); however, the differences of hBD-3 expression were not statistically significant (phBD-3=0.1869>0.05) (Table 2).

When the tissues with stomach cancer were separated according to $H$. pylori infection. we found that infection in the tissue of $14 / 24(58.3 \%)$ patients, $10 / 24$ (41.6\%) patients' tissues with stomach cancer were not observed as having the infection. When the levels of hBD-3 and hCAP-18/LL-37 expressions of the stomach adenocarcinoma were correlated separately, there was no significant association between H. pylori infection status and the hBD-3 and hCAP-18/LL-37 expressions in normal and tumor tissues ( $\mathrm{p}>0.05)$ (Table 3 ).

No statistically significant correlation was found between the expression of peptides and the age and gender of the patients $(p>0.05)$.

\section{DISCUSSION}

Peptides of the defensin and cathelicidin are found in humans protecting epithelia against invading pathogenic microorganims such as bacteria, viruses and fungi, and assisting neuthrophils and platelets. Beyond their antimicrobial function, these peptides are known to be multi-functional. In fact, it has been demonstrated their multiple roles as mediators of inflammation with effects on epithelial and inflammatory cells, and the impact these roles have over such diverse processes as proliferation, immune induction, wound healing, cytokine release,chemotaxis, protease-antiprotease balance, and redox homeostasis. ${ }^{22}$

Studies in recent years, have occurred two opposing ideas about the role AMPs in cancer biology. The first of them, AMPs is cytotoxic to cancer cells and have a protective role against cancer $^{23}$, and the other is the contribution of cancer development taking part in tumorogenesis, angiogenesis and tumor metastasis. ${ }^{19.24}$

Although the number of studies on the role of AMPs in the tumorigenesis is increasing, little is known about the relationship between AMPs and the mechanisms of tumor development.

Looking into a limited number of these studies. Lisovskiy and coworkers reported that hBD-2 mRNA expression may be induced in vitro also by growth factors EGF or TGF- $\alpha$ and that it is linked to the malignant phenotype of epithelial cells originated from human cervix. ${ }^{25}$ 
Table 3. The statistical differences of hBD-3 and hCAP-18/LL-37 expressions between stomach adenocarcinomas of non-infected and infected with $\mathrm{H}$. pylori

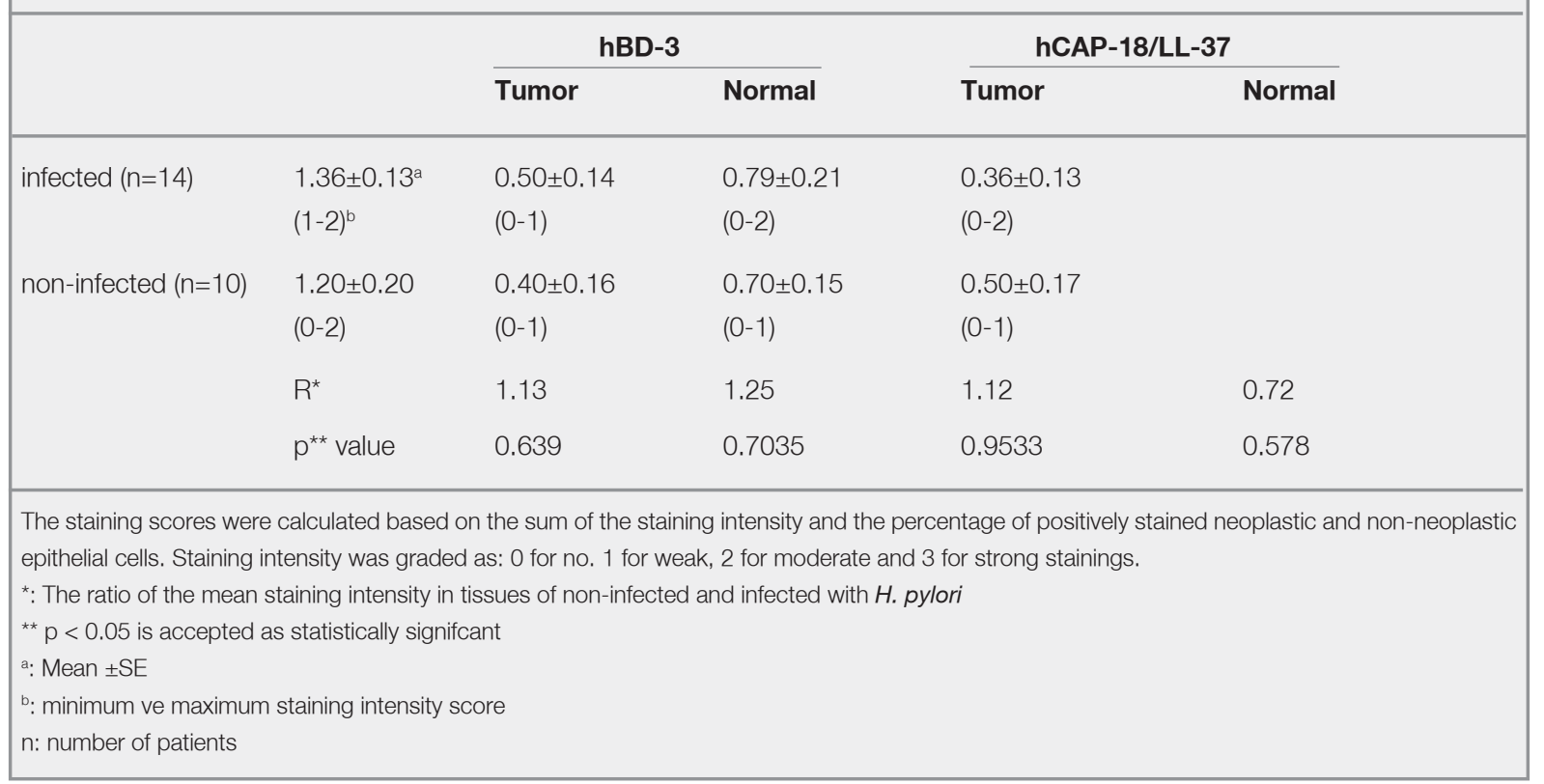

In renal epithelial neoplasms. hBD-1 was found to be significantly downregulated in conventional clear cell carcinoma. ${ }^{26}$ Shnitsar and coworkers investigated hBD-3 gene expression in A431 cell line and human cervix tumours. They found that in human cervix epithelium. the increase in hBD-3 mRNA expression was associated with malignant phenotype. ${ }^{9}$ Gambichler and coworkers investigated the expression of hBDs in patients with basal cell carcinoma (BCC) and healthy controls. They found that hBD-1 levels in healthy controls and non-lesional skin of BCC patients were significantly higher than the levels observed in tumour tissue. Moreover. BCCs showed significantly increased mRNA expression of hBD-2 as compared to controls. They found no significant difference between lesional mRNA levels for hBD-3 and those levels observed in controls. ${ }^{6}$

In this study, in the tumor tissues. defensin antimicrobial peptide (hBD-3) expression was found significantly higher compared to normal healthy tissues an observation that was in line with the literature.

Some studies showed that cathelicidin stimulates angiogenesis by a direct interaction with endothelial cells. The tumor promoting effect of cathelicidin could be mediated by the angiogenic effect of the peptide. The growth of vessels is a critical factor in the expansion of tumors. ${ }^{27}$ The hCAP18/LL-37 is known to stimulate angiogenesis by a direct effect on endothelial cells, ${ }^{28.29}$ von Haussen and coworkers reported that EGFR were phosphorylated by hCAP-18/LL-37 and, as a result, the downstream MAP kinase signaling pathway was activated. Moreover. they emphasized that hCAP18/LL-37 was acting as a growth factor for human lung cancer. ${ }^{19}$ Coffelt and coworkers investigated the expression of hCAP-18/LL-37 in patients with ovarian cancer and healthy controls, and they reported that hCAP-18/LL-37 was significantly overexpressed in ovarian tumors. and suggested that hCAP-18/LL-37 may contribute to ovarian tumorigenesis through direct stimulation of tumor cells. initiation of angiogenesis and recruitment of immune cells. ${ }^{17}$ Heilborn and coworkers found that in breast cancer hCAP18/LL-37 was strongly expressed in the tumor cells and they emphasized that hCAP18/LL-37 may promote tumor cell growth in breast cancer. ${ }^{18}$

In this study, although the hCAP-18/LL-37 expression was higher in colon. stomach and lung adenocarcinomas tissues than normal tissues, significant differences were observed tumor tissues and normal tissues in patients with colon and lung adenocarcinoma. 
Involvement of hBD-2 in the pathophysiology of H. pylori-induced gastritis was demonstrated. ${ }^{14}$ However. hBD-2 and hBD-1 overexpression was revealed both in $\mathrm{H}$. pylori-positive and $\mathrm{H}$. pylorinegative gastric biopsy samples from patients with gastritis. ${ }^{8}$ Markeeva and coworkers ${ }^{27}$ showed that the hyperexpression of hBD-2 on mRNA and protein levels was registered in 6 of 17 gastric tumor samples compared to respective controls. However, they did not relate the hBD-2 expression with the presence of anti- H. pylori antibodies in the blood serum of the patients.

Similarly, in the present study, we suggest that the hBD-3 and hCAP-18/LL-37 expression patterns were not related to the presence of $H$. pylori in the patients, because. high expression levels of hBD-3 and hCAP-18 peptides were not associated with $\mathrm{H}$. pylori infection in gastric cancer.

In conclusion, this study showed that human beta defensin (hBD-3) and human cathelicidin peptide hCAP-18/LL-37 expressions in colon, stomach and lung adenocarcinomas tissues were higher than normal tissues. In addition. because there was no correlation between the expression of the AMPs and $H$. pylori infection in stomach cancer, we believe that AMPs can play a role during the tumorogenesis. However, we think that to elucidate the role of antimicrobial peptides in tumorogenesis, studies need to be done analyzes examining the relationship between AMPs and tumorigenic, metastatic and angiogenic markers. Future studies with substantially larger numbers of cancer patients are needed to study hBD-3 and hCAP-18/LL-37 expressions in parallel with other antimicrobial peptides.

\section{REFERENCES}

1. Zasloff M. Antimicrobial peptides of multicellular organisms. Nature 415: 389-1395, 2002.

2. Brown KL, Hancock RE. Cationic host defense (antimicrobial) peptides. Curr Opin Immunol 18: 24-30, 2006.

3. Bullard RS, Gibson W, Bose SK, et al. Functional analysis of the host defense peptide Human Beta Defensin-1: New insight into its potential role in cancer. Mol Immunol 45: 839-848, 2008.
4. Bose SK, Gibson W, Bullard RS, Donald CD. PAX2 oncogene negatively regulates the expression of the host defense peptide human beta defensin-1 in prostate cancer. Mol Immunol 46: 1140-1148, 2009.

5. Donald CD, Sun CQ, Lim SD, et al. Cancer-specific loss of beta-defensin 1 in renal and prostatic carcinomas. Lab Invest 83: 501-505, 2003.

6. Gambichler T, Skrygan M, Huyn J, et al. Pattern of mRNA expression of $B$-defensins in basal cell carcinoma. BMC Cancer 6: 163, 2006.

7. Shestakova T, Zhuravel E, Bolgova L, et al. Immunohistochemical analysis of beta-defensin-2 expression in human lung tumors. Exp Oncol 32: 273-276, 2010.

8. Yoshimoto T, Yamaai T, Mizukawa N, et al. Different expression patterns of beta-defensins in human squamous cell carcinomas. Anticancer Res 23(6C): 4629-4633, 2003.

9. Shnitsar VM, Lisovskiy IL. Soldatkina MA, Nespryadko SV, et al. Human beta-defensin 3 (hBD-3) expression in A431 cell line and human vulval tumors. Exp Oncol 26: 328-330, 2004.

10. Lisovskiy IL, Soldatkina MA, Lytvyn DI, et al. Pattern of betadefensin-2 and EGFR mRNAs expression in cervical and vulval cancer cells. Exp Oncol 23: 248-252, 2001.

11. O'Neil DA, Cole SP, Martin-Porter E, et al. Regulation of human beta-defensins by gastric epithelial cells in response to infection with Helicobacter pylori or stimulation with interleukin-1. Infect Immun 68: 5412-5415, 2000.

12. Wada A, Mori N, Oishi K, et al. Induction of human beta- defensin-2 mRNA expression by Helicobacter Pylori in human gastric cell line MKN45 cells on cag pathogenicity island. Biochem Biophys Res Commun 263: 770-774, 1999.

13. Wehkamp J, Schimidt K, Herrlinger KR, et al. Defensin pattern in chronic gastritis: hBD-2 is differentially expressed with respect to Helicobacter pylori status. J Clin Pathol 56: 352-357, 2003.

14. Uehara N, Yagihashi A, Kondoh K, et al. Human beta-defensin-2 induction in Helicobacter pylori-infected gastric mucosal tissues: antimicrobial effect of overexpression. J Med Microbiol 52: 41-45, 2003.

15. Bajaj-Elliott M, Fedelli P, Smith GV, et al. Modulation of host antimicrobial peptide (beta-defensin 1 and 2) expression during gastritis. Gut 51: 356-3561, 2002.

16. Zanetti M. The role of cathelicidins in the innate host defenses of mammals. Curr Issues Mol Biol 7: 179-196, 2005.

17. Coffelt SB, Waterman RS, Florez L, et al. Ovarian cancers overexpress the antimicrobial protein hCAP-18 and its derivative LL-37 increases ovarian cancer cell proliferation and invasion. Int J Cancer 122: 1030-1039, 2008.

18. Heilborn JD, Nilsson MF, Jimenez Cl, et al. Antimicrobial protein hCAP18/LL-37 is highly expressed in breast cancer and is a putative growth factor for epithelial cells. Int $\mathrm{J}$ Cancer 114: 713-719, 2005 
19. von Haussen J, Koczulla R, Shaykhiev R, et al. The host defence peptide LL-37/hCAP-18 is a growth factor for lung cancer cells. Lung Cancer 59: 12-23, 2008.

20. Hase K, Murakami M, limura M, et al. Expression of LL-37 by human gastric epithelial cells as a potential host defense mechanism against Helicobacter pylori. Gastroenterology 125: 1613-1625, 2003.

21. Kilic M, Oguztuzun S, Karadag AS, et al. The Relationships of Cathelicidin. hBD-1. hBD -2 and hBD -3 in Patients with P. versicolor. T. inguinalis and T. pedis Infections. Adv Biol Res 7: 228-233, 2013.

22. Marshall SH, ArenasG. Antimicrobial peptides: A natural alternative to chemical antibiotics and a potential for applied biotechnology. Electr J Biotechnol 62: 271-284. 2003.

23. Mader JS, Hoskin DW. Cationic antimicrobial peptides as novel cytotoxic agents for cancer treatment. Expert Opin Investig Drugs 15: 933-946, 2006.

24. Weber G, Chamorro Cl, Granath F, et al. Human antimicrobial protein hCAP18/LL-37 promotes a metastatic phenotype in breast cancer. Breast Cancer Res 11: 1-13. 2008.

25. Lisovskiy I, Soldatkina M, Lytvyn D, et al. Expression of defensin genes in A431 and M-HeLa cell lines and in tumors of human vulvae and cervix. Exp Oncol 23: 119-122. 2001.

26. Muller CA, Markovic-Lipkovski J, Klatt T, et al. Human alphadefensins HNPs-1. -2. and -3 in renal cell carcinoma: influences on tumor cell proliferation. Am J Pathol 160: 1311-1324, 2002.

27. Carmeliet P, Jain RK. Angiogenesis in cancer and other diseases. Nature 407: 249-257, 2000.

28. Steinstraesser L, Ring A, Bals R, et al. The human host defense peptide LL37/hCAP accelerates angiogenesisin PEGT/ PBT biopolymers. Ann Plast Surg 56: 93-98, 2006.

29. Koczulla R, von Degenfeld G, Kupatt C, et al. An angiogenic role for the human peptide antibiotic LL-37/hCAP-18. J Clin Invest 111: 1665-1672, 2003.

\section{Correspondence}

Dr. Serpil OĞUZTÜZÜN

Kırıkkale Üniversitesi

Fen Fakültesi

Biyoloji Bölümü

71450 Yahşihan, KIRIKKALE / TURKEY

Tel: (+90.318) 3574242 / 4031

Fax: (+90.318) 3572461

e-mail: soguztuzun@yahoo.com 